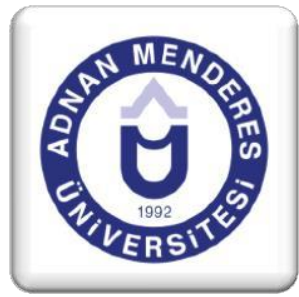

\title{
Organizasyon Yapısını Belirleyen Faktörler ve Yapının Önemi
}

\author{
Murat ÇUBUKCU ${ }^{1}$
}

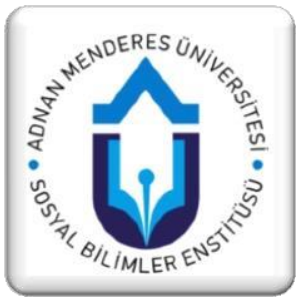

\section{ÖZET}

Bir işletmenin kuruluşunda organizasyon yapısı büyüklüğüne, çalışmaların kapsamına, dağıtım kanallarına ve geleceğe ilişkin genişleme projelerine en uygun olanı seçilerek düzenlenmelidir. Organizasyonel yapı genel olarak, organizasyonel amaçları gerçekleştirmek için yapılacak görevler arası ilişkileri, faaliyetlerin gruplandırılmasını, yetki devrini, organizasyondaki yatay ve dikey bilgi akışını gösterir. En gelişmişinden en ilkeline kadar örgütler bir yapıya gereksinme duymuş ve kişiler arasındaki ilişkileri en uygun biçimde düzenleyecek bir örgütsel yapı kurmuşlardır. Günümüz koşullarında işletmeler seçilen politika ve stratejileri uygulaya bilmek için saptanan planları gerçekleştirecek bir organizasyon yapısı oluşturmalıdır. Çünkü başarılı bir uygulama büyük ölçüde bir organizasyon yapısına bağlıdır. Makalemizde uygulamada en çok karşılaşılan organizasyon yapısı çeşitlerinin açıklanması ve organizasyon yapısını belirleyen faktörler ve örgüt yapıları konusunda yazında yapılan tartışmalar bir araya getirilerek ortaya konulması amaçlanmıştır.

Anahtar Kelimeler: Organizasyon, Organizasyon Yapıları, Yapı, Organizasyon Şemaları, Strateji.

\section{The Factors and the Importance of the Organization Structure}

\begin{abstract}
The organizational structure of an enterprise should be organized in a way that best suits its size, scope of work, distribution channels and future expansion projects. The organizational structure in general shows the functional relationships, the grouping of activities, the delegation of authority, the horizontal and vertical information flow in the organization in order to realize the organizational goals. From the most advanced to the earliest, the organizations needed a structure and formed an organizational structure to organize the relationships among the people in the most appropriate way. In today's conditions, businesses should create an organizational structure that will implement the plans that are set to implement selected policies and strategies. Because a successful application depends on a large organization structure. It is aimed to explain the most common types of organizational structure in our practice and it was aimed to bring together the discussions made in the literature about the factors determining organization structure and organizational structures.
\end{abstract}

Keywords: Organization, Organizational Structure, Structure, Organization Charts, Strategy.

\footnotetext{
${ }^{1}$ Phd., Uludağ Üniversitesi Sosyal Bilimler Enstitüsü, İşletme, Doktora, Nilüfer/Bursa
} 


\section{Giriș}

Geçmişten günümüze insanlar, amaçlarını etkin ve verimli bir şekilde gerçekleştirebilmek için aralarında işbirliği ve koordinasyona dayalı faaliyetlerde bulunmuşlardır. İşletmelerde, günümüzün hızla değişen küresel ekonomisinde hayatta kalabilmek ve büyümek için, organizasyon yapılarını çarpıcı bir şekilde değiştirmek zorunda kalmışlardır. Aynı zamanda yeni fikirler üreten insanlara değer verip, müşterileri ve meslektaşları ile işbirliği yaparlarken, yaptıkları yeniliklerle işletme için bir gelecek değeri yaratan radikal yeni yapıları oluşturup; en iyi geleneksel yapılarını da sürdürmeye devam etmişlerdir (Pearce ve Robinson, 2015: 297).

İşletmelerin doğru stratejik yaklaşımı seçmelerinde, örgütün faaliyet gösterdiği yapısal koşulları, kaynakları, yetenekleri ve stratejik zihniyeti belirleyici olur (Kim ve Mauborgne, 2009: 73). Stratejilerin uygulanması, yetki ve görevlerin bölünmesi, yetki ve görevler arasında bütünleşik bir dizi koordinasyon mekanizması ile ilgili kararları içeren, örgüt yapısı vasıtasıyla gerçekleşir (Parthasarthy ve Sethi, 1992: 103). Örgütlerin amacı hedefe en az masraf ve fedakârlıkla ulaşılması için gerekli düzenin yaratılması, örgüt üyelerinin birleşmesi ve bunların tam bir uyum halinde işbirliği yapmalarıdır. Organizasyon yapısının düzenlenmesi, maliyetleri düşürücü ve etkinliği artırıcı olmalıdır. Isşletmeler ve iş birimleri stratejiyi destekleyecek tarzda yapılandırılmış ve örgütlenmiş olmalıdır (Luecke, 2015: 90).

Organizasyonun stratejik kaynaklarının uygun bir şekilde geliştirilmesi, doğru kullanılması ve kontrol edilmesi, organizasyonun yapısının özenli bir biçimde tasarlanması ve doğru süreçlerin bu yapı içine yerleştirilmesiyle elde edilir (Barutçugil, 2013: 475). Organizasyon yapıs1, sorumlulukların, görevlerin ve kişilerin örgütlenme biçimidir. Örgütün yetkisini, hiyerarşisini, birimlerini, bölümlerini ve koordinasyon mekanizmasını içerir (Carpenter ve Sanders, 2009: 21). Organizasyon yapısı, iç ilişkiyi, işbölümünü ve örgüt içindeki etkinliği koordine etme araçlarını tanımlamaktadır. Yapı, kararların alındığı, emeğin bölünmesinin ve bölümlerin nasıl oluşturulduğu ve hangi kuralların, politikaların ve prosedürlerin faaliyetleri yönettiği gibi konuları içerir (Hodge Et al., 2003: 16).

Uluslararası stratejik yönetim yazınında örgüt yapısını belirleyen faktörler ve örgüt yapıları önemli bir tartışma sahasıdır. Stratejilerin örgüt yapılarına önemli etkileri vardır. Bu nedenle örgütün yapısal bileşenlerinin strateji ile uyumlu olması gerekliliği stratejik yönetim yazınında tartışıla gelmiştir (Miller, 1986: 234). Organizasyonların yapısı üzerinde yoğunlaşan çalışmalar genellikle organizasyonları bir yapı ve bu yapıyı oluşturan süreç olarak ele almış ve bu alanda çalışmalar yapmışlardır (Mirze, 2016: 5).

Çağdaş stratejik yönetim düşüncesi 1960'larda doğmuş olmakla birlikte, işletmelerde stratejik yönetim ile örgüt yapıları konularında yapılan çalışmaların 1980'lerden sonra artış gösterdiği ve stratejik yönetiminin bağımsız bir bilim dalı olarak ele alınmaya başlandığı tespit edilmiştir. Yerel literatürde de yabancı literatüre paralel olarak 2000'li yıllardan sonra stratejik yönetim alanında yapılan araştırmalarda artış olduğu görülmüştür. İç ve dış çevre koşullarına uygun ve stratejileri ile uyumlu doğru örgüt yapıları ile işletmelerin verimli ve etkinlikleri artırılarak performanslarına ve hedeflerinin gerçekleştirilmesine olumlu katkı sağlanmış olunacaktır.

Makalemiz hazırlanırken yerli ve yabancı kaynak taraması yapılmıştır. Çalışmamızda, literatürde örgüt yapısı konusunda yapılan belli başlı araştırmalar kavramsal çerçevede ortaya konulmuştur. Gerekli literatür incelemesi ile yazına katkı sağlanması hedeflenmiştir. Makalemizde organizasyon yapısını belirleyen faktörler ve yapının önemi üzerine yapılan çalışmalar ve tartışmaların kuramsal bir derleme ile bir arada ortaya konulması amaçlanmıştır. Makalemizde, işletmeler için organizasyon yapısının önemi ve organizasyon 
yapısını belirleyen ve etkileyen belli başlı faktörlerin ortaya konulması sağlanmıștır. Makalemizde belli başlı organizasyon yapısı türlerini ve bu yapı tiplerinin çeşitlerini inceleyeceğiz.

\section{2. İşletmelerde Organizasyonun Önemi ve Gerekliliği}

İşletmelerde organizasyon yapısının önemi konusunda literatürde pek çok çalışma yapılmıştır. A. Chandler tarafından geliştirilen ve tartışmaya açılan strateji yapı etkileşimi en önemli çalışmalardan biridir. En ilkelinden en gelişmişine kadar bütün işletmelerde bir yapıya gereksinim vardır. Yönetim biliminin kurucusu sayılan Henry Fayol, organizasyonu, işletmenin faaliyette bulunması için gerekli olan makine, işgücü, doğal kaynaklar ve kapital gibi faktörlerle donatmak olarak tanımlamıştır (Birdal ve Aydemir, 1992: 45).

Her şey değişir ve başarı değişikliklere reaksiyon göstermedeki hıza bağlıdır. Sadece işleri doğru yapmak başarı getirmez; doğru işleri hızlı yapmak, hızlı şirket olmak, hiyerarşiden ve bürokrasiden arındırılmış, çabuk karar alabilen, yatay, akışkan ve müşteri odaklı organizasyonlar kurmak gerekir (Metin, 2003: 2). Örgüt yapısı, örgütlerin karar alma hızlarını etkileyen önemli bir faktördür (Chen, 2012: 28-29). İşlerin birbirleriyle, işlerin çalışanlarla ve çalışanların birbirleriyle ilişkilerinin bütünü işletme yapısını oluşturmaktadır (Ülgen ve Mirze, 2013: 382).

İşletmeler küçük ise, yapılan işler sınırlıdır ancak işletme büyüdükçe yapılan işler, yönetim kademeleri ve iş bölümü fazlalaşmakta ve bu işleri tek bir kişinin yapması zorlaşmaktadır. Böyle bir işletmenin amaçlarına etkin ve verimli bir biçimde ulaşabilmesi için faaliyetlerin belirlenmesi, belirli bir sira ve düzene konması gerekmektedir. Bundan dolayıdır ki, yöneticiler yönetimin bir fonksiyonu olan organizasyona gerek duymuşladır.

Organizasyon, hedeflerin uygulamaya konulmasını sağlayan bir tür sistemdir. Tek başına insanın belirli bir amaca ulaşması mümkün olmamaktadır. Çok sayıda insanın yer aldığı topluluklarda da bir düzen olması gerekmektedir. Bu kapsamda örgütlenmeye ihtiyaç duyulmaktadır (Örücü, 2013: 119). Organizasyon yapısı, bir organizasyondaki görevler, kişiler ve kaynaklar arasındaki etkileşimi ve sorumlulukları biçimlendiren ve genelde pozisyonları veya unvanları basamaklandırarak gösteren, çoğunlukla da piramit şeklinde olan bir şemadır (Ülgen ve Mirze, 2013: 298).

Chandler (1962), Homburg, Krohmer, Workman (2004), Hrebiniak (2006) gibi bazı yazarlar yapının stratejiyi izlediğini bildirirlerken, Hall (2004) ve Certo, Peter (2005) gibi diğerleri göstermişlerdir ki stratejiyi tanımlayan organizasyon yapısıdır. Brenes, Mena, Molina (2008), Galan, Sanchez-Bueno (2009), Amitabh, Gupta (2010), Kich, Pereira (2011) gibi araştırmacılarda yaptıkları araştırmalarda, yapının ve stratejinin örgütsel çevrede karşılıklı olarak etkilendiği sonucuna varmışlardır (Neis et al., 2016: 480). Chandler örgüt yapısının izlenen stratejilerden etkilendiğini belirtmiş ve stratejiyi ayrı bir işletme fonksiyonu olarak ele almıştır. Ona göre stratejiler ve stratejik kararlar örgütlerin rekabetçi bir performans sergilemeleri ve sermayeyi örgütlemelerine yardımcı olur (Çakır ve Atak, 2013: 280).

\section{Organizasyon Yapısına Etki Eden Faktörler}

Başarılı bir organizasyon kurmanın en iyi yolu yoktur. Bir organizasyon için en uygun yapı kendi bağlamına, yani hedeflerine, teknoloji, boyut ve kültürüne bağlıdır. Bu kavramların belirli bir tasarım ile konfigürasyonu ve uyum sağlamasında yapı önemli bir unsurdur (Hodge et al., 2003: 45). Örgütsel yapıya ilişkin yazında "yönetici sayısı, otonomi, 
merkezileşme, karmaşıklık, yetki devri, farklılaşma, biçimselleşme, bütünleşme, kontrol alanı, uzmanlaşma, profesyonelleşme, standardizasyon, dikey kademe sayısı" gibi birçok unsur tanımlanmaktadır (Robbins, 1990: 82-83).

İyi yöneticiler örgütleri şekillendirir. Örgütsel boyut, yapısal ve bağlamsal boyut olmak üzere iki grupta ele alınmaktadır. Yapısal boyut, bir örgütün içsel karakteristiklerini tanımlamada kullanılan etiketleri sağlar. Bağlamsal boyut, büyüklük, teknoloji ve hedeflerini de içerecek şekilde örgütün tamamını karakterize eder. Örgüt, büyüklüğüne, biçimselleşme, merkezileşme, uzmanlaşma, profesyonelleşme derecesine, personel oranlarına göre tanımlanabilir (Daft, 2015: 14-15).

Bir örgüt teknoloji, hizmet verilen nüfus ve gerçekleştirilen hizmetlerden etkilendiği için, organizasyonel tasarımda önemli değişiklikler, bu unsurların karışımını değiştirmeyi gerektirecektir. $\mathrm{Bu}$ değişikliğin sağlanabilineceği yolların bazıları; dikey entegrasyon, sunulmakta olan popülasyonların boyutlarındaki artışlar ve nesneyi veya müşteriyi kuruluşa dahil etmesi sayılabilir. Örgütlerde farklılıklar varsa, yapıları da değişmelidir (Tosi, 2009: 84). Perrow (1967) teknoloji ile biçimsellik, standardizasyon, merkezilik, çalışanın yetenek seviyesi, iletişim ve eşgüdüm gibi örgütün yapısal unsurları arasında ilişki olduğunu vurgulamıştır (Sözen ve Basım, 2012: 106).

\section{1. Çevre ve Örgüt Yapısı}

Çevre organizasyon için firsat ve tehditler yaratır. Çok güçlü olanları hariç, organizasyonlar bu firsat ve tehditleri istedikleri şekilde yönlendiremezler. Bu durumda yapılacak şey çevresel koşullara en uygun davranışlarda bulunarak organizasyonun faaliyetlerini devam ettirebilmektir (Mirze, 2016: 79). Ackoff ve Emery (1972) çevreyi "sistemin parçası olmayan ancak değiştiğinde sistemin durumunda da değişikliklere neden olan bir dizi unsurdan oluşan bir olgu" olarak tanımlamışlardır (Ackoff ve Emery, 1972). Sistemin çevresini sistemin durumunu etkileyen değişkenlerin tümü oluşturmaktadır. Bu değişkenler; demografik yap1, ekonomik-siyasi-hukuki koşullar, kültürel yapı, coğrafi ve teknolojik koşullar şeklinde sıralanabilir (Hall, 1977: 304).

Bazı araştırmacı grubuna göre strateji, örgüt ve çevrenin uyumlaştırılması süreci olarak görülmekte ve stratejiyi çevresel koşullarla uyumlamak gerekmektedir (Venkatraman ve Camillus, 1984: 514). Strateji ve yapı arasındaki karşılıklı nedensellik konusunda Mintzberg'e göre, hiçbir devam eden organizasyon, strateji değiştiğinde maziyi temizlemeyecektir. Çevre ve yapı geçmişim önemli bir parçasıdır, dolayısıyla bu yapı stratejiyi takip ediyor. Çünkü yürürken sol ayak sağ ayağı izler. Gerçekte, strateji ve yap1 organizasyonu desteklemektedir. Hiçbiri öncelik taşımaz, herbiri diğerinden önce gelir ve örgüt birleşinceye kadar, örgüt yeni bir pozisyona atladığından onu izler (Amburgey ve Dacin, 1994: 1429).

Örgüt teorisi literatüründe, Thompson (1967), Lawrence ve Lorsch (1967), Donaldson (1995), uyum kavramını, çevre-strateji ilişkilerinden ziyade çevre-yapı ilişkilerini vurgulama eğiliminde olan yapısal koşul bağımlılık teorisi ile ilişkilendirilmiştir. Literatürde, belirli yapıların belirli ortamlar için daha uygun olduğunu ve çevre koşullarındaki değişikliklerin yapı seçiminin yeniden değerlendirilmesini gerektiği öne sürülmüştür (Zajac et al., 2000: 431).

Çevre konusunda koşul bağımlılık kuramının öncü niteliğindeki çalışması Londra Tavistock enstitüsünden Fred Emery ve Eric Trist 1965 yılında yayınlamış oldukları makalede, işletmelerin faaliyette bulundukları çevreyi 4 grupta sınıflandırmışlardır (Emery ve Trist, 
1965: 30-31); durgun, rastgele çevre, durgun kümelenmiş çevre, dengesiz, reaktif çevre ve çalkantılı çevre (Cole, 2004: 80-81). Yine Londra Tavistock Enstitüsü’nden Tom Burns ile G.M. Stalker'in 1961 yılında İngiltere'de yapmış oldukları araştırma ile işletmelerin örgüt yapı ve yönetim uygulamalarının dış çevre koşullarından nasıl etkilendiğini bulmaya çalışmışlardır. Araştırmaları ile örgüt yapısının ve örgütte kullanılan süreçlerin çevre koşullarına bağlı bağımlı değişken olarak ele alınmaları durumunda, "en iyi” sayılabilecek bir örgüt yapısına ulaşmak için izlenecek prensipler dizisi bulunmadığı genel sonucuna ulaşmışlardır (Burns ve Stalker, 1961: 12-96). Ayrıca Burns ve Stalker (1961), örgüt yapılarını ve yapının bir unsuru olan yönetim politikalarını bir sınıflandırmaya tabi tutmuşlardır. Bürokrasinin, merkezileşmenin iş bölümü ve uzmanlaşmanın yüksek olduğu örgüt yapıları "mekanik" örgüt yapısı, beraber çalışmanın, kararlara katılımın ve fikir alışverişinin yüksek olduğu örgüt yapıları "organik" olarak isimlendirilmiştir (Sözen ve Basım, 2012: 93).

Lawrence ve Lorsch 1967 yilında 'Organization and Environment' adlı eserlerinde, belirsiz çevrelerde başarılı işletmelerin başarısız işletmelere oranla daha farklı bir yapıya sahip olduğunu, bu işletmelerin daha gelişmiş entegrasyon uygulamalarına sahip olduğunu ortaya koymuştur. Çevrenin taleplerini karşılama çabasında, departmanlar arasında olması gereken işbirliği ihtiyacını tanımlamak için 'entegrasyon' kavramı kullanılmıştır. Yaptıkları araştırmada, entegrasyonu yüksek organizasyonların her türlü ölçülebilir finansal standardının, entegrasyonu düşük işletmelere oranla daha başarılı olduğu ortaya konulmuştur. Daha az belirsiz çevrelerde ise, bu işletmeler daha az farklılaşmış ve daha az gelişmiş entegrasyon uygulamalarına sahip olmuşlardır (Powell, 1992: 119).

Örgüt-çevre ilişkileri konusunda diğer önemli bir "teorik" çalışma James Thompson (1967) çalışmasıdır. Thompson'a göre örgütler bir hedefe ulaşmak için ortaya çıkmışlardır ve istenilen hedeflere ulaşacak planlar yapmaları konusunda teknoloji ve çevresel belirsizlikler gibi birtakım engeller ile karşılaşmaktadırlar. Thompson, örgüt ve çevresi arasındaki karşılıklı bağımlılığı tanımlamıştır. Örgüt ve çevre karşılıklı bağımlıdır ve örgütlerin çevre üzerinde çok kısıtlı etkileri söz konusudur. Örgütler rasyonalite sağlamak için çevresel bağımlılığı ve belirsizliği azaltmaya çalışırlar. Örgütler çevredeki belirsizliği iki şekilde yönetirler. Bunlardan birisi, örgütün çevreye uyumu adına yapılan içsel uyarlamalardır. Diğeri ise, dışsal stratejiler ve çevre ile etkileşim şekilleridir (Sözen ve Basım, 2012: 97-98).

Duncan (1972)'nın araştırmasında; karar verirken hangi çevresel faktörler tarafından etkilendiklerini, bu organların üyelerinin çevresel unsurları nasıl değerlendirdiklerini ve belirsizliğin kararlar üzerinde oynadığı rolü araştırmıştır. Ulaştığı en önemli sonuç; bir örgütün amaçlarını gerçekleştirmesi, kullandığı karar mekanizmaları ile karar organlarının yapısının, çevresel unsurlarının özelliklerine uygun olmasına bağlı olduğunu vurgulamasıdır. Duncan (1972)'nın çevrenin kavramlaştırılmasında kullandığı basit-karmaşık ve statikdinamik (durgun-değişken) boyutları belirtmiştir (Duncan, 1972: 325). Basit ve karmaşıklık boyutu çevre içinde var olan ve faaliyette bulunan unsur sayısı ile durgun veya değişkenlik boyutu ise var olan ve faaliyette bulunan çevresel unsurların değişim hızı ile ölçülmektedir (Mirze, 2016: 14). Duncan (1979) çalışmasında basitçe yapının stratejik seçimi kısıtladığını savunmuştur (Fredickson, 1986: 280).

\subsection{Teknoloji ve Örgüt Yapısı}

Joan Woodward (1965) tarafindan teknolojiyi bir koşul bağımlılık faktörü olarak ortaya koyan öncü nitelikte çalışmalar yapılmıştır. Woodward (1965), teknoloji ögesini örgütsel yapının önemli bir değişkeni olarak belirlemiştir (Sargut ve Özen, 2010: 36). Woodward'a 
(1965) göre başarılı olabilen örgütler kullandıkları teknoloji ile yapılarını uyumlaştırabilen örgütlerdir (Sözen ve Basım, 2012: 102-103). Woodward, her teknoloji türü için değişik bir örgüt yapısının uygun olacağını belirtmiştir (Gannon, 1979: 77).

Örgüt teorisi literatüründeki çok sayıda çalışma, Woodward (1965) çalışması gibi, teknolojinin örgütsel yapıyı etkilediğini iddia etmektedir (Parthasarthy ve Sethi, 1992: 91). Thompson (1967), çevrenin hem örgüt yapısını hemde teknolojinin ve çevrenin birlikte örgütün genel yapısını nasıl etkilediğini ile ilgilenmiştir (Tosi, 2009: 85). Teknoloji konusunda olduğu gibi çevre konusunda da Thompson sentezci niteliği ağır basan bir model geliştirmiştir. Thompson (1967)'a göre biçimsel örgüt yapısı hangi esasa dayanırsa dayansın, her örgütte sorunları, teknikleri, yaklaşımları birbirinden farklı üç ayrı alt-sistem görmek mümkündür. Bunlar; teknik (operasyonel) alt-sistem, kurumsal (stratejik) alt-sistem ve koordinatif (yönetimsel) alt-sistemdir (Thompson, 2003: 15-17).

Perrow (1967) teknolojinin örgüt yapısını belirleyen önemli bir unsur olduğunu vurgulamıştır. Bu çalışmasında örgütlerin kullandığı teknoloji türlerini sınıflandırmış ve teknoloji türlerini örgüt yapıları ile ilişkilendirmiş̧tir (Sözen ve Basım, 2012: 105). Koşul bağımlılık yaklaşımının teknoloji ile ilgili yönüne ilişkin yukarıda açılanan önemli araştırmalarda ortak sonuç; örgüt yapısının belirlenmesinde ve örgütlerde kullanılan çeşitli süreçlerin etkinliğinde kullanılan teknolojinin önemli bir rol oynadığıdır. Yani örgüt yapısı örgütün sahip olduğu teknoloji ile yakından ilişkilidir ve her farklı teknoloji farklı bir örgüt yap1s1 gerektirmektedir.

\section{3. Örgütlerin Büyüklüğü ve Örgüt Yapısı}

Yap1 bir örgütün anatomisidir. Bir işletmenin yapıs1, görev ve sorumluluklarının belirlenmesi, bunlar arasındaki davranış bağlantılarının kurulması demektir (Dinçer, 2013: 310). Yapılan araştırmalarda, işletme büyüklüğü ile strateji ve yapı arasındaki korelasyonun güçlü olduğu görülmüştür (Grinyer ve Ardekani, 1981: 471).

Büyüklük kavramı Aston Grubu araştırmasında da ele alınmış olsa da büyüklük ile ilgili en temel araştırma Peter Blau (1970) tarafindan yapılmıştır. Blau çalışmasında, örgütün büyüklüğü arttıkça örgütün farklı seviyelerindeki farklılaşmanın giderek yavaşlayan şekilde artacağını öne sürmüştür. Burada örgütün büyüklüğünü personel sayısı belirlemektedir. Ancak büyüme arttıkça farklılaşmanın ve idari kadronun büyümesi aynı hızda olmayacak ve direnç oluşacaktır. Blau'nun (1970) bu araştırmasından ortaya çıkan temel sonuç, örgüt büyüdükçe yapının daha karmaşık hale geleceği, daha bürokratik ve mekanik yapıya dönüşeceğidir (Sözen ve Basım, 2012: 110). Blau, örgütlerin artan büyüklüklerinin, sorumluluklarının alt bölümlere ayrılması sonucunu da getirdiğini söylemektedir (Sargut ve Özen, 2010: 59). Blau ve Schoen (1971)'e göre organizasyonun büyüklügünün yapısını etkilediği kabul edilir. Örgüt boyutu büyükse, resmiyetleştirme yüksek olmalıdır (Burton ve Obel, 2004: 31).

Bir örgütün, çevresine gereken nitelikte ve sürede uyarlanabilmesi için, bürokrasi ile değil Adhokrasi ile yönetilmesi gerekmektedir. Adhokrasi, çevreye uyma yeterliliği olan bir örgüt yapıs1 ve yönetimidir. Adhokrasi'de yönetimin, kökleşik ilkelere bağlanmadan uzmanlığa dayalı canlı yapılar oluşturmasını ve kararların örgütün alt basamaklarında alınmasını yeğlemesi gerekir (Toffler, 1981: 119). Adhokrasi sözcüğü ile anlatılmak istenen, bürokrasinin birçok düzeyinde bürokratik boşluklara rastlayan ve insanların ne yapılacağının bilmedikleri için üstesinden gelmedikleri yeni konulara eğilen örgütsel mekanizmalardır (Yeniçeri ve İnce, 2005: 438-439). Bürokratik yapılar aynı zamanda stratejik planlamanın 
doğuşu ve gelişmesi için olumsuz olan bir kültüre sahiptir. Çünkü çok fazla resmi ve prosedürel bir sistem içerirler (Hall ve Saias, 1980: 155).

\subsection{Stratejik Koşul Bağımlılık Yaklaşımı}

En önemli temsilcileri Hinnings, Hickson, Pennings ve Schneck $(1971 ; 1974)$ olan güç okulunun iki temel kuramı stratejik koşul bağımlılık kuramı ve kaynak bağımlığı kuramıdır (Pennings et al., 1974: 22-23). Burns ve Stalker (1961), Lawrence ve Lorsch (1967) ve Reimann (1974) gibi bazı araştırmacılar, örgütsel tasarım ve performans arasındaki ilişkileri inceleyen çalışmalarda bulundular. Bu çalışmalar, örgütsel tasarımın etkinliğinin, şarta bağlı faktörler ile örgüt yapısı arasındaki uyumdan kaynaklandığını belirten durumsallık (koşul bağımlılık) yaklaşımı kavramını getirdi. Böylece Mintzberg'i (1979) takiben, bir örgütün yapısını tasarlarken, koşul bağımlılık faktörleri örgüt tasarımının özelliklerini belirleyecektir (Ortega et al., 2010: 1284).

Koşul bağımlılık, bir şeyin başka bir şeye bağlı olduğu anlamına gelir. Koşul bağımlılık yaklaşımı, tüm örgütler için, en uygun veya en iyi yolun bulunmadığını belirtmektedir. Yaklaşımda yöneticilerin işletmenin yönetim stratejilerini belirlediklerinde bağlamsal faktörleri göz önüne almaları gerektiğini ifade etmektedir (Hodge et al., 2003: 17). D. Hall ve M. Saias yaptıkları araştırmaların sonucunda, uygulamada, strateji ve yapı arasındaki ilişkilerin her iki yönde de olabileceğini göstermişlerdir. Yap1 stratejiyi izlemediği, eşleşmediği sürece verimsizlik ortaya çıkıyor. Strateji, yap1 ve çevre arasındaki ilişkilerin simetrik olduğu kabul edilmiştir. Yapıyı hesaba katmamak verimsizliğe yol açabilir (Hall ve Saias, 1980: 161-162).

Yapısal koşul bağımlılık kuramının biçimlenmesinde bazı temel araştırmalar kalıcı katkılar sağlamışlardır. Woodward (1965), teknoloji ögesini örgütsel yapının önemli bir değişkeni olarak belirlemiş̧ir. Burns ve Stalker, yeniliklerden ve buluşlardan yola çıarak çevrenin örgüt üzerinde ki baskısını gündemde tutmuştur. Aston grubu, örgütsel büyüklük üzerinde çalışmalar yaparak, örgütsel yapının ölçülmesinde önemli bir aşama sağlamıştır. Grubun üzerinde çalıştı̆̆ dört yapısal değişken olan; merkezleşme, uzmanlaşma, biçimselleşme ve standartlaşmaya ilişkin veriler, sonraki araştırmaları da derinden etkilemiştir (Sargut ve Özen, 2010: 36).

Örgütlerde koşul bağımlılık yaklaşımına göre, hiçbir organizasyon yapısı, her durum için geçerli değildir. Yöneticiler ve akademisyenler tarafından evrensel olarak en iyi organize edilme şekli bulunmadığı, koşul bağımlılık ve duruma bağlı bir yaklaşımın gelişmesine yol açtığı kabul edilir (Byars, 1987: 122). Örgütler belirli stratejileri izleyerek çevrelerindeki belirsizliği azaltmaya çalışırlar. Miles (1980)'a göre örgütler çevrelerindeki değişimlere uymak için stratejiler izlerler (Miles, 1980: 295).

Stratejik koşul bağımlılığı yaratan unsurlar, örgütün hem içinde hem de dışında onun hedeflerine ulaşmasında kritik rol oynayan olayları ve faaliyetleri ifade etmektedir. Örgütteki hangi aktörlerin önemli bir güce sahip olacaklarını belirleyen koşul bağımlılık unsurlarının altını çizen kuramda stratejik koşul bağımlılık kuramı olarak adlandırılmıştır. Kuramı, gücün yapısal kaynakları üzerine odaklanmış, güç farklılıklarını açıklamak için kişilerin psikolojik özelliklerini kullanmamıştır (Hinnings et al., 1974: 22).

Thompson (1967), koşul bağımlılık adını kullanmamasına karşın; örgütsel yapı ve dinamiklerin teknoloji, amaçlar, çevresel baskılar ve eşgüdüm sorunları gibi belirleyicilere dayandığını ileri sürmüştür. Donaldson (1996), kuramın paradigmasında üç çekirdek ögenin yer aldığını ileri sürmüştür. Birincisi; koşul bağımlılık ile örgütsel yapı arasındaki ilişkidir. 
İkinci olgu, koşul bağımlılığın örgütsel yapıyı belirlemesidir. Üçüncü olarak da örgüt yapısının değişkenleriyle koşul bağımlılık arasında bir uyum söz konusudur. Uyum oluştuğunda örgüt yüksek performansa erişir, uyumsuzluk başladığında örgütün performansı düşer (Sargut ve Özen, 2010: 37-38).

Koşul bağımlılık kuramında, her koşulda geçerli tek bir örgüt yapısının olmadığı, yöneticilerin örgüt yapılarını içlerinde bulundukları bağlama; yani koşul bağımlılık faktörlerine, uyarlamaları gerektiği belirtilmektedir. Kurama göre, örgütlerin etkili olabilmesi için tek yol koşullar ile uyumlu bir örgüt yapısını tasarlamalarından geçmektedir. Kuram tarafından öne sürülen en temel koşul bağımlılık faktörleri; çevre, teknoloji, büyüklük ve strateji olarak ortaya konulmuştur. Kuramda, koşul bağımlılık faktörlerine ek olarak örgütlerde yapısal unsurlarda; iş bölümü, uzmanlaşma, kontrol, otorite, iletişim ve yönetim olarak ortaya konulmuştur. Kuramda, yapısal faktörler ile durumsal faktörler arasındaki ilişkilere ilişkin önermeler geliştirilmiştir (Sözen ve Basım, 2012: 92).

\section{Organizasyon Yapısı ve Çeşitleri}

Klasik kuram örgütün formel yapı ve ilişkileri üzerinde durduğundan, örgütün görünmeyen yönünü, iç ilişkilerini ihmal etmiştir. Bu iç ilişkilerin doğru bir şekilde teşhis ve yorumlanması neo-klasik görüşün gelişmesiyle mümkün olabilmiştir. Örgüt buzdağına benzetilmekte, örgütün görünmeyen yönü görünen yüzünden çok daha büyük ve karmaşık olduğu ve görünen yüzü biçimsel düzenlemeleri aksettirirken, görünmeyen yüzü karmaşık beşerî ilişkileri ve algıları ifade etmektedir (Bumin, 1990: 23-24). Organizasyonlar, kabul edilen amaçlar, inançlar ve değerler sisteminin bütünüdür (Barutçugil, 2004: 207). Strateji, örgüt tasarımını etkileyen önemli bir faktördür (Daft, 2015: 117).

Bugünün işletmeleri, sahip oldukları yapılarını, gittikçe dışsal ve içsel ilişkilerden meydana gelen, özenle hazırlanmış bir şebeke olarak görmeye başlamıştır. Sanal organizasyonlar, geçici şebekeler olarak tanımlanabilir. Birbirine enformasyon teknolojisi ile bağlanarak yeteneklerini, pazara erişimi ve maliyetleri paylaşan bağımsız işletmelerden, tedarikçiler, müşteriler, alt yüklenicilerden ve hatta rakiplerden oluşan geçici şebekedir. Çevik organizasyon, yüksek karlılık getiren temel yeteneklerini tanımladıktan sonra bu yetenekler çerçevesinde bir sanal organizasyon oluşturan işletmedir (Pearce ve Robinson, 2015: 313).

1960'lı ve 1970'li yıllarda çeşitli yazarlar, Burns ve Stalker (1961), Chandler (1962), Lawrence ve Lorsch (1967), Pugh, Hickson ve Hinings (1969) ve Rumelt (1974) araştırmalarında alternatif yapı türlerini açıklamışlardır. Araştırmacılar, yaptıkları katkıların bir sonucu olarak organik ve mekanik, işlevsel ve bölümsel veya iş akışı bürokrasisi gibi isimler taşıyan farklı yapılara düzenli olarak atıfta bulunmuşlardır. Mitzberg (1979), önceki araştırmalarının sentezi olarak literatürde ortaya çıkmaya başlamış beş form oluşturmuştur (Fredickson, 1986: 290).

Burns ve Stalker mekanik ve organik örgüt yapılarını, Miles ve Snow arayıcılar, analizciler, savunmacılar ve tepki vericiler şeklinde sinıflandırırken, Mintzberg basit yap1, makine bürokrasi, profesyonel bürokrasi, bölümlendirilmiş formlar ve adhokratik örgüt yapıları üzerinde durmuşlardır (Yeloğlu, 2008: 161). Konsept organizasyon yapıs1, nispeten katı (mekanik) durumdan, nispeten gevşek (organik) duruma kadar değişebilir. Burns ve Stalker'e göre, organik organizasyonlar; etkileşim yoluyla görevlerin yeniden düzenlenmesi ve sürekli olarak yeniden tanımlanması, kontrol, otorite ve iletişim ağ yapısı ve yatay iletişim vardır. Mekanik organizasyonlarda ise; bir pozisyonun işlevsel sorumluluklarına ilişkin hakların ve itirazların ve yöntemlerin kesin olarak tanımlanması, hiyerarşik bir kontrol yapısı 
ve dikey iletişim kalıpları vardır (Tosi, 2009: 8).

Yap1, yetki ve sorumluluk kanallarının açıklığa kavuşturulması ve iletilmesine katkıda bulunarak, yöneticiye eşgüdüm sağlamada yardımcı olur (Can, 2005: 176). Yöneticiler, çalışanlarını işletme amaçlarına yönlendirmek ve denetlemek için, resmi organizasyon yapısına güvenirler. Bazı organizasyonlarda resmi organizasyon yapısı çok katı ve hiyerarşi piramidi diktir. Bazı organizasyonlarda ise, takımlar ve yöneticiler, işletme amaçlarına ulaşmak için, çapraz fonksiyonlardaki ve farklı fonksiyonlardaki kişilerle de çalışırlar (Ceylan ve Anbar, 2014: 200).

Hızlı değişen ve karmaşık bir çevrenin belirsizliği, organik bir örgütü zorunlu kılarken; farklı bölüm veya takımların oluşmasına, bunlar arasında koordinasyona, değişime uyuma ve dolayısıyla esnekliğe neden olur (Dinçer, 2013: 324). Sanal organizasyonun kalbinde ise bazı kritik işlevleri yerine getiren temel bir organizasyon bulunmaktadır. Bu temel yetki alanının dışındaki işlevler, geçici veya sözleşmeli işçiler veya ittifak kurduğu diğer kuruluşlar tarafindan yapılabilir. Sanal organizasyonun dezavantaj1, çekirdek organizasyonun geleneksel bir organizasyondan daha az kontrol sahibi olmasıdır (Hodge et al., 2003: 207).

İşletmeler organizasyonel yapılarını seçerken belirli faktörleri göz önünde bulundurmalıdır. $\mathrm{Bu}$ faktörler: işletmenin amacı, gerçekleştirilen faaliyetler, organizasyon ilkeleri ve yönetim ekibi ve şekilleridir (Birdal ve Aydemir, 1992: 46). Organizasyonun biçimi, her işlevin ortamına ve çevrenin gerektirdiği değişikliklere bağlıdır (Tosi, 2009: 123). Bir organizasyon büyüdükçe, farklı örgütsel yapılar gereklidir. Örgütler basitten karmaşık bir süreklilik içerisinde büyürler. Organizasyonun boyutu büyüdükçe, farklı organizasyonel yapılar gerekli olmaktadır (Byars, 1987: 123). Organizasyon türleri genel olarak dört ana başlık altında toplanır; dikey örgüt, dikey ve kurmay örgüt, fonksiyonel örgüt ve karma örgüt şeklinde sıralanabilir (Şimşek, 1999: 149). Literatürde en yaygın kullanılan bazı organizasyon yapıları sınıflandırılarak açıklanmaya çalışılmıştır.

\subsection{Biçimsel ve Biçimsel Olmayan Organizasyon Yapıları}

Örgütleme süreci veya örgüt tasarımı sonucunda ortaya çıkan yapı formel (resmi - biçimsel) örgüt yapısıdır. Örgüt şeması böyle bir formel yapıyı gösterir. Biçimsel olmayan (informel) örgüt ise, biçimsel örgüt yapısındaki kademe ve mevkilerin çalışanlarca doldurulması neticesinde oluşan ve herhangi bir ön planlama ve bilinçli bir düzenleme eseri olmayan, ancak bireylerarası ilişkiler sonucu ortaya çıkan bir yapıdır (Şimşek, 1999: 138). Resmi yapı, resmen görevlendirilmiş rollerden ve ilişkiyi kuran kişiye veya ilişkiyi kuran kişilerden bağımsız olarak bulunan ilişkilerden oluşur. Resmi olmayan organizasyon, örgütlerin politik niteliğinin bir sonucudur ve resmi olarak kurulmasından ziyade orada çalışan insanlarla gelişir (Hodge et al., 2003: 31-32). İşin koordinasyonu ve karş11ıklı uyumda basitçe informel iletişim yoluyla sağlanabilir (Mintzberg, 2014: 3).

Bir işletmenin resmi organizasyon yapısının oluşturulmasında, dikey organizasyon, dikey kurmay organizasyon ve fonksiyonel organizasyon gibi farklı organizasyon yapı modelleri kullanılabilir. Dikey organizasyon yapısında, faaliyetler, en üst düzeyden, orta ve alt düzeye doğru birbiriyle bağlantılıdır. Üst yöneticiler işletmenin misyonunu ve amaçlarını belirledikten sonra, görevleri tanımlayıp, bu görevleri yapacak kişileri seçerler. $\mathrm{Bu}$ organizasyon yapısında çalışanlar, sadece bir yöneticiye karşı sorumludurlar ve onların verdikleri görevleri yaparlar. Dikey kurmay örgüt yapısı, dikey organizasyona bir kurmay (danışman) bölümün ilave edilmesi ile oluşur. Fonksiyonel örgüt yapısında ise, fonksiyonel 
yetki, genellikle en üst düzeyde bir yönetici tarafından değil, kendi alanında uzman kişiler tarafindan kullanılır (Ceylan ve Anbar, 2014: 201-202).

Matris organizasyon yapısı en karmaşı bağlantı aracıdır. Matris organizasyonu çift yetkili bir yapı oluştururken, karmaşık bağımlılıkların koordinasyonu ve çevredeki belirsizliklere hızlı tepki göstermede en etkili olduğunu kanıtlamıştır (Tosi, 2009: 139). Matris organizasyonun amac1, geleneksel komuta yapısındakinden daha yüksek seviyede koordinasyonu temin edebilmektir. İş, tipik komuta örgütünde ki uzmanlaşmış bölümlerden farklı bir şekilde, bir proje çerçevesinde örgütlenmektedir. Her proje bitinceye kadar bir başka yöneticinin sorumluluğuna verilmiştir. Proje sona erdiğinde personel kendi eski görevine dönecektir (Ertürk, 2009: 103-105).

Matris yapı, güçlü bir yatay bağlantı biçimidir. Matris örgütün en benzersiz özelliği ürün bölümlerinin ve işlevsel yapıların (yatay ve dikey) eşzamanlı olarak uygulanmasıdır. Matris yapı, örgütsel amaçlara ulaşmada teknik uzmanlık, ürün yeniliği ve değişiklik aynı anda önemli olduğunda kullanılır. Yatay bağlantı mekanizmaları ile desteklenmiş olan işlevsel, ürüne göre veya coğrafi yapıların işe yaramadığı durumlarda matris yapı sorunun çözümü olarak görülmüştür (Daft, 2015: 75).

\subsection{Basitten Karmaşığa Doğru Organizasyon Yapıları}

Küçük örgütlerin yapısal biçimi çoğunlukla çizgidir. Hat organizasyonun özellikleri, küçük işletmelerde özellikle avantajlı olmasını sağlar. Bu avantajlar organizasyonun büyümesiyle kaybolur (Tosi, 2009: 45). En basit organizasyon yapisı olan emir-komuta tipi organizasyon genellikle küçük işletmelerde kullanılmaktadır. Basit organizasyon yapısı, sadece işletme sahibinin ve birkaç çalışanın bulunduğu, görevlerin, sorumlulukların ve iletişimin son derece gayri resmi olduğu ve görevlerin direkt kontrol altında gerçekleştirildiği bir yapıdır. Tüm stratejik ve operasyonel kararlar, işletmenin sahibi veya ortaklar tarafindan oluşturulmuş ufak bir takım tarafından alınır (Pearce ve Robinson, 2015: 298).

Örgütte tüm karar verme gücü tek bir noktada ve nihai olarak tek bir kişinin elinde olduğu zaman buna merkezileşmiş yapı olarak adlandırabiliriz. Bu güç birçok kişiye dağılmış olduğu zaman ise merkezileşmemiş yapı olarak adlandırabiliriz. Merkezileşme örgütte karar verme tasarımında en katı koordinasyon aracidır (Mintzberg, 2014: 181-182). Bir organizasyonda genel olarak alt, orta ve üst kademeler olmak üzere üç kademe belirlemek mümkündür. Üst kademe stratejik düzeyi, orta kademe koordinatif düzeyi ve alt kademe de operasyonel düzeyi ifade eder (Şimşek, 1999: 148).

Organizasyonun temel faaliyetlerini yürütenlere fikir veren, yol gösteren, yardım ve hizmet eden bu uzman kişilerin oluşturdukları kurmay organları, uzmanlaşma ve iş bölümünün doğal bir sonucu olarak görülmektedir. Kurmay organlar, işletmenin temel amaçlarını gerçekleştiren kumanda organlarının en etkin biçimde çalışmalarına yardımcı olur ve onları destekler. Bu yapının oluşmasında rol oynayan bir etmen, uzman organlara kuruluşlarda doğan sürekli ihtiyaçtır (Birdal ve Aydemir, 1992: 47).

Fonksiyonel organizasyon yapısı görevlerin, kişilerin ve teknolojilerin çalışabilmesi için işlerin ayrı fonksiyonel gruplara (pazarlama, üretim, finans gibi) bölündüğü: işletmenin ürün ve hizmetlerine yönelik faaliyetlerini bütünleştirmek ve koordinasyonu sağlamak için biçimsel prosedürlerin artırılmış olduğu yapıdır. Bölümlere ayrılmış organizasyon yapısı, işletme içerisinde merkezi bir ofisten yönetilen, göreceli olarak özerk, her biri farklı ürün ve hizmetler sunan ve farklı fonksiyonel uzmanlara sahip olan birimler veya bölümlerden oluşan yapıdır. Matris organizasyon yapısı, atanan personelin hem fonksiyonel hem de proje 
veya ürün yöneticisine bağlı olduğu organizasyon yapısıdır (Pearce ve Robinson, 2015: 300303).

Komite tipi organizasyonlarda, her yönetici ona bağlı yöneticiler grubu ile birlikte bir karar grubu olarak çalışmaktadır. Böylece bir alt grubun üyesi olan kişi diğer bir üst grubunda (komite) üyesi olmaktadır. Dolayısıyla kişiler arası ilişkiler yerine, gruplar arası ilişkiler sistemi gözönüne alınmalıdır. Likert'e göre, her yönetici organizasyona bağlı yöneticiler grubu ile birlikte bir karar grubu olarak çalışacaktır. Böylece bir alt grubun üyesi olan kişi diğer bir üst grubunda yani diğer bir üst komitenin de üyesi olacağından fonksiyonel bölümlerden ve hatta alt birimlerden organizasyonun bütününe kadar varan bir komite yönetimine ulaşılacaktır (Birdal ve Aydemir, 1992: 48-49).

\section{3. İşletmelerin Büyüme Aşamalarına Göre Organizasyon Yapıları}

Organizayon yapıları işletmelerin büyüme aşamalarına göre de sınflandırılmıştır. İ̧̧letmeler büyüdükçe, yapılması gereken işler ve bunları yapacak kişilerin sayısı da artar. Yönetim kademeleri oluşur ve iş bölümü fazlalaşır. Yapılması gereken faaliyetler ve çalışanlar arttıkça, faaliyetleri belirli bölümler altında toplamak, çalışanları ortak işletme amacına ulaşacak şekilde düzenlemek, bölümler ve çalışanlar arasındaki ilişkileri belirlemek daha da önemli hale gelir (Ceylan ve Anbar, 2014: 199). Örgüt büyüdükçe ve işi yapanlar arasında daha karmaşı bir iş bölümü kullanırken gittikçe artan oranda doğrudan denetim ihtiyacı hissedilir (Mintzberg, 2014: 18).

Literatürde işletmelerin geçirdikleri büyüme aşamalarına göre organizasyon yapılarını sınıflandırılmıştır; basit yapı, fonksiyonel yapı, bölümsel yapı ve sektörel yap1 (holding yapısı) şeklinde. İşletmenin birden fazla benzer ürün üretmesi ve buna bağlı olarak işletme faaliyetleri çeşitlendirilmesi sonucunda fonksiyonel yapının üzerine başka yönetim kademeleri eklenir ve bölümsel veya çok bölümlü yapı oluşturulur. Diğer bir ifadeyle bu örgüt yapısında bölümlendirme ürün veya pazar esas alınarak yapılır (Birdal ve Aydemir, 1992: 49-51).

Bir Holding organizasyon yapısında iki tip Holding işletme vardır; tam (saf) holding ve karma holding'dir. Tam (saf) holdingte, holding şirketin ana faaliyet konusu yoktur. Temel faaliyetleri, diğer şirketlerin hisse senetlerini ele geçirerek onların denetimi ve yönetimi üzerinde söz sahibi olmaktadır. Karma tip holding ise, diğer işletmelerin hisse senetlerine sahip olarak onların faaliyetlerini denetleme olanağına paralel olarak kendine özgü bir ana faaliyet konusuna sahiptir (Pekiner, 1988: 188).

\subsection{Serbest Biçimli Organizasyon Yapıları}

Serbest biçimli (organik) örgüt yapısında işletmelerin, bürokratik sürecin olumsuz etkilerinden zarar görülmesinin engellenmesi amaçlanır, örgütsel hiyerarşiye karşı durulur ve çalışanların önemsiz kontrollerden arındırılarak akılcı çabaların girişimi teşvik edilir (Hodgetts, 1997: 137). Esnek organizasyonlar, kaynak israfinı azaltarak ve üretim sürecinin her aşamasında değişen koşulları dikkate alan, yaratıcı düşünce tarzını entegre ederek emek ve sermayenin verimliliğini artırır. Esnek işletmeler; insiyatif, yaratıcılık, problem çözme, değişime açıklık gibi işgücü niteliklerine önem vermekte ve bu yetenekler için daha yüksek bir ücret ödemeyi kabul etmektedir (Aktan ve Vural, 2004: 161).

Esnek yapılı bir örgütte yapı; değişken, kendini yenileyen ve organiktir. Esnek yapı, özellikle emir birliği olmak üzere, yönetimin klasik ilkelerine en az uygunluk gösteren yapıdır. $\mathrm{Bu}$ 
yapıda, bilgi ve karar süreci nerede yenilik yapılacaksa oraya informel ve esnek bir şekilde akar. Aslında basit yapıda da organik bir yapı vardır ve yenilik yapabilir. Esnek yapı bilgi ve becerileri eğitim programları ile geliştirilmiş profesyonel uzmanlar istihdam etmeli ve bu uzmanlara yetki vermelidir (Mintzberg, 2014: 433-434).

İstikrarlı bir çevrede örgüt dikey kontrol, verimlilik, uzmanlaşma, standart süreçler, merkezi karar alma gibi unsurlara önem veren geleneksel bir yapıda olabilir. Ancak hızla değişen bir çevre yatay koordinasyon ile takımlar ve diğer mekanizmaların birlikteliğinden oluşan daha esnek bir yapıyı gerektirebilir (Daft, 2015: 117). Çok çeşitli nedenlerden dolayı serbest şekilli yapılar artış göstermektedir. Yöneticiler anlık değişimler ve zorluklarla başa çıkabilmek için daha esnek örgütler talep etmektedirler. Yöneticiler eskiye oranla yeni örgütsel yapılardan daha etkin olarak faydalana bilmektedirler. Teknolojik gelişmeler örgütsel dizaynlarını modernize etmeleri için baskı yapmaktadırlar. Serbest biçim yapılar çok sayıda eski problemlere bir çözüm içerebilmektedir (Hodgetts, 1997: 138-139).

Burns ve Stalker (1961), yapıyı kendi içinde bir süreç ve organizasyonu kendi kaderini belirleyebilmesi için birlikte tutmanın bir aracı olarak görmüş̧ür. Dinamik olarak değişen ve belirsiz ortamlarda çalışan örgütler organik/esnek yapılara ve süreçlere ihtiyaç duyma eğiliminde iken daha istikrarlı ortamlarda mekanik olma eğilimindedirler (Teare et al., 1998: 62). Dolayısıyla çevre ne kadar dinamikse, örgütsel yapıda o kadar organik/esnek olacaktır (Neis et al., 2016: 480). Hız ve esnekliğin önem kazandığı günümüzde işletmelerin rekabette öne geçebilmeleri için esnek örgüt yapılarına sahip olabilmeleri önemli bir stratejik avantaj haline gelmiştir.

\section{Sonuç}

Yönetim tarzları değiştikçe, örgüt modelleri de değişmektedir. $\mathrm{Bu}$ anlamda piyasalar ve teknolojide yaşanan çok hızlı değişimler ve gelişmeler önümüzdeki dönemde daha yeni yönetim modellerini ortaya çıkarabilecektir. Önemli olan yönetim modellerinin işletmeler için neyi ifade ettiğidir. İşletmeler küreselleşme ve teknolojik gelişmeler ile uluslararası platforma yönetim modellerini hızlı öğrenme ve kendi bünyelerinde uygulama şansı bulmuşlardır. Aktarılan bir yönetim modeli, bütün işletmeler için teorik anlamda geçerli olabilmektedir. Önümüzdeki dönemde yeni yönetim modelleri gündeme geldiğinde, işletmelerimiz için neyi ifade ettiğinin araştırılması faydalı olacaktır.

İşletmelerin organizasyonunda yapısal dengeye dikkat edilmelidir. Organizasyon yalnız işletme kurulurken göz önünde tutulacak bir şema değil, işletmelerin yaşamları boyunca uygulanacak bir disiplin sürekli olarak gözden geçirilecek ve geliştirilecek bir düzendir. İşletmenin değişen çevre koşullarında amaçlarına ulaşabilmesi için esnek, değişebilir bir organizasyon yapısına sahip olması gerekir. İşletme dinamik ve yaşayan bir varlık olup, çevrenin ekonomik, teknolojik politik, toplumsal ve doğa koşullarındaki değişmelerin büyük ölçüde etkisinde kalır.

İşletmeler büyüdükçe ve çalışma koşulları değiştikçe organizasyon yapısı belirli aralıklarla, günün gereklerine uygun duruma getirilir. İşletmelerin büyümeleri ve dolayısıyla yönetim fonksiyonun gelişmesi, insan unsuruna günden güne daha çok önem verilmesi yapısal düzen ile ilgili incelemeleri gerekli kılmış ve bu hızlı gelişmelerin sonucunda işletmelerin organizasyon yapılarında gerekli değişiklikler yapılması bir gereklilik haline gelmiştir. En gelişmişinden en ilkeline kadar örgütler bir yapıya gereksinme duymuş ve kişiler arasındaki ilişkileri en uygun biçimde düzenleyecek bir örgütsel yap1 kurmuşlardır. Örgütsel yap1 işletmelerin büyüklüğü, çalışma dalına, gelişme planlarına, dağıtım kanalları gibi 
özelliklerine göre farkl1lık arz eden örgütsel yapının düzenlenmesi maliyetleri düşürücü ve etkinliği artırıcı bir etken olarak görülebilir.

Yöneticiler işletmelerin örgütsel yapısını kurarken, yalnız önsezilerinin etkisinde kalmamalı, mümkün olduğu kadar deneysel yöntemlerden yararlanarak rasyonel çözümler getirmelidirler. İnsanlar örgütleri bilinçli ya da bilinçsiz olarak yaratırlar. Örgütlerin amacı hedefe en az masraf ve fedakârlıkla ulaşılması için gerekli düzenin yaratılması, örgüt üyelerinin birleşmesi ve bunların tam bir uyum halinde iş birliği yapmalarıdır. İşletmeler organizasyonel yapılarını seçerken; işletmenin amacı, gerçekleştirilen faaliyetler, organizasyon ilkeleri ve yönetim ekibi ve şekilleri gibi belirli faktörleri göz önüne almalıdırlar. Yönetim tarzları değiştikçe, örgüt modelleri de değişebilecektir.

Yapılan yerli ve yabancı literatür taraması sonucunda, belirli bir amaca, etkili ve verimli bir biçimde ulaşabilmek için sürekli ancak esnek olarak kurulacak olan organizasyon yapısı insan unsurundan, en yüksek yarar ve tasarrufu sağlayacak, ilişkileri basitleştirecek ve haberleşmeyi kolaylaştıracak biçimde düzenlenmeleri gerektiği sonucuna ulaşılmıştır. Özellikle 1980'lerden sonra dünyada ve ülkemizde de 2000'li y1llardan sonra stratejik yönetimin bağımsız bir bilim dalı olarak geliştiği görülmektedir.

Organizasyon yapısını belirleyen ve etki eden faktörler ve strateji-yapı uyumu konusunda, özellikle uygulamaya yönelik araştırmaların daha fazla yapılması gerektiği düşünülmektedir. İşletmelerin stratejik yönetime bakış açılarının tespitine ve uygulanmakta olan stratejilerin örgüt yapılarına etkilerine veya örgüt yapılarının seçilecek veya uyguladıkları stratejiler üzerinden etkilerinin tespitine yönelik çalışmalara ihtiyaç vardır. Araştırma sonuçları ile, stratejik yönetim biliminin gelişmesine katkı sağlanması, işletmelerin strateji seçimlerinde rehberlik sağlanması ve mevcut durumlarına ayna tutulması sağlanarak geleceğe yönelik bir öngörü oluşturula bilineceğine inanılmaktadır. 


\section{KAYNAKÇA}

ACKOFF, L. R. ve EMERY, F. E. (1972). On Purposeful Systems. Tavistock Publications, London.

AKTAN, C. C. ve VURAL, İ. Y. (2004). Yeni Ekonomi ve Yeni Rekabet. Türkiye İşveren Sendikaları Konfederasyonu Rekabet Dizisi: 1, Yayın No: 253, Ankara.

AMBURGEY, T. L. ve DACIN T. (1994). As The Left Foot Follows The Right The Dynamics Of Strategic And Structural Change. Academy of Management Journal, 37(6): 1427-1452.

BARUTÇUGIL, İ. (2004). Stratejik İnsan Kaynakları Yönetimi. 1.b., Kariyer Yayıncılık, İstanbul.

BARUTÇUGIL, İ. (2013). Stratejik Yönetim. 1.b., Kariyer Yayıncılık, İstanbul.

BİRDAL, İ. ve AYDEMİR, N. (1992). Yönetim Teorileri. Sistem Yayıncılık, İstanbul.

BUMIN, B. (1990). İşletmelerde Organizasyon Geliștirme ve Çatıșmanın Yönetimi. Gazi Üniv. İİBF, Ankara.

BURNS, T. ve STALKER, G. M. (1961). The Management of Innovation. Tavistock, London.

BURTON, R. M. ve OBEL, B. (2004). Strategic Organizational Diagnosis and Design: The Dynamics of Fit. 3. Ed., Springer Science HBusiness Media, New York.

BYARS, L. L. (1987). Strategic Management. 2.b., Harper\&Row Publishers, New York.

CAN, H. (2005). Organizasyon ve Yönetim. 7. Bask1, Siyasal Kitabevi, Ankara.

CARPENTER, M. A. ve SANDERS, Wm. G. S. (2009). Strategic Management. 2.b., Pearson International Edition, New Jersey.

CEYLAN, A. ve ANBAR, A. (2014). Modern İşletmecilik. Ekin Yayınevi, Bursa.

CHEN, S. T. (2012). The Effect of Absorptive Capacity and Decision Speed on Organizational İnnovation. Contemporary Management Policy and Practice, 8(1): 2750.

COLE, G. A. (2004). Management Theory and Practice. 6. Ed., South Western, 2004.

ÇAKIR, Ö. ve ATAK, M. (2013). Bilgi Çağında Yönetim. 1.b., Paradigma Akademi Yayınları, Edirne.

DAFT, R. L. (2015). Örgüt. 10.b., Çeviri Editörü: Ömür N. Timurcanday Özmen, Nobel Akademi Yayınc1lı, İstanbul.

DİNÇER, Ö. (2013). Stratejik Yönetim ve İşletme Politikası. 9. b., Alfa Yayım, İstanbul.

DUNCAN, R. B. (1972). Characteristics of Organizational Environments and Perceived Environmental Uncertainty. Administrative Science Quarterly, 17(3): 313-327.

EMERY, F. E. ve TRIST, E. (1965). The Causal Texture of Organizational Environments. Human Relations, 18: 21-32.

ERTÜRK, M. (2009). İşletmelerde Yönetim ve Organizasyon. 4.b., Beta Yayınevi, İstanbul.

FREDICKSON, J. W. (1986). The Strategic Decision Process and Organizational Structure. Academy of Management Review, 11(2): 280-297. 
GANNON, M. J. (1979). Organizational Behavior: A Managerial and Organizational Perspective. Little Brown.

GRINYER, P. H. ve ARDEKANI, M. Y. (1981). Strategy, Structure, Size and Bureaucracy. Academy of Management Journal, 24(3): 471-486.

HALL, R. H. (1977). Organizations: Structure and Process. 2. Edt.. Prentice-Hall.

HALL, D. J. ve SAIAS, M. A. (1980). Strategy Follows Structure. Strategic Management Journal, 1: 149-163.

HININGS, C. R., HICKSON, D. J., PENNINGS, J. M. ve SCHNECK, R. E. (1974). Structural Conditions of Intraorganizational Power. Administrative Science Quarterly, 19(1): 22-44.

HODGETTS, R. M. (1997). Yönetim. 5. Baskı, Çevirenler: Canan Çetin ve Esin Can Mutlu, Der Yayınları, İstanbul.

HODGE, B. J., ANTHONY, W. P. ve GALES, L. M. (2003). Organization Theory. 8.b., Prentice Hall, New Jersey.

KIM, C. W. ve MAUBORGNE, R. (2009). How Strategy Shapes Structure. Harvard Business Review, September, 87(9): 72-80.

LUECKE, R. (2015). Strateji. 3.b., Harvard Business Press, Çeviren: Turan Parlak, İş Bankası Kültür Yayınları, İstanbul.

METIN, C. (2003). Capital, 2. http://www.capital.com.tr/capital-dergi/sabanci-son-yillardabiraz-yavaslamis-haberdetay-1146., (25.02.2018).

MILES, R. H. (1980). Macro Organizational Behavior. Santa Monica, Goodyear, California.

MILLER, D. (1986). Configurations of Strategy and Structure. Strategic Management Journal, 7(3): 233-249.

MINTZBERG, H. (2014). Örgütler ve Yapıları. 1.b., Çeviri Editörü: Ahmet Aypay, Nobel Akademik Yayınc1lık, Ankara.

MIRZE, S. K. (2016). Organizasyon Tasarımı ve Yapılandırma. 1.b., Beta Basım, İstanbul.

NEIS, D. F., PEREIRA, M. F. ve MACCARI, E. A. (2016). Strategic Planning Process and Organizational Structure: Impacts, Confluence and Similarities. Brazilian Business Review, 14(5): 479-492.

ORTEGAS, E. M. P., AZORIN, J. F. M. ve CORTES, E. C. (2010). Competitive Strategy, Structure and Firm Performance. Management Decision, 48(8): 1282-1303.

ÖRÜCÜ, E. (2013). Modern İşletmecilik. 9. b., Dora Yayın, Bursa.

PARTHASARTHY, R. ve SETHI, S. P. (1992). The Impact Of Flexible Automation On Business Strategy And Organizational Structure. Academy oí Management Review, 17(1): 86-111.

PEARCE, J. A. ve ROBINSON, R. B. (2015). Stratejik Yönetim. 12. Edt., Çev. Mehmet Barca, McGraw-Hill Irwin, Nobel Yayın, Ankara.

PEKİNER, K. (1988). İşletme Denetimi. İ.Ü. İşl. Fak. Yayını, İstanbul. 
PENNINGS, J. M., HININGS, C. R., HICKSON, D. J. ve SCHNECK, R. E. (1974). Structural Conditions of Intra Organizational Power. Administrative Science Quarterly, March, 19(1): 22-44.

POWELL, T. C. (1992). Organizational Alignment as Competitive Advantage. Strategic Management Journal, 13(2): 119-134.

ROBBINS, S. P. (1990). Organization Theory: Structure, Design, and Applications. 3rd ed., Prentice Hall, New Jersey.

SARGUT, S. A. ve ÖZEN, Ş. (2010). Örgüt Kuramları. 2. Baskı, İmge Kitabevi, Ankara.

SÖZEN, C. H. ve BASIM, N. H. (2012). Örgüt Kuramları. 2. Bask1. Beta, İstanbul.

ŞİMŞEK, Ş. (1999). Yönetim ve Organizasyon. 5. Baskı, Nobel Yayın, Ankara.

TEARE, R. E., COSTA, J. ve ECCLES, G. (1998). Relating Strategy, Structure and Performance. Journal of Workplace Learning, 10(2): 58-75.

THOMPSON, J. D. (1967). Organizations in Action: Social Science Bases of Administrative Theory. McGraw-Hill: New York.

THOMPSON, J. D. (2003). Organizations in Action: Social Science Bases of Administrative Theory. (with a new preface by Mayer N. Zald and W. Richard Scott), Taylor\&Francis, New York.

TOFFLER, A. (1981). Şok - Gelecek Korkusu. 3.b., Çev. A.Selami Sargut, Altın Kitaplar Yayınevi, İstanbul.

TOSI, H. L. (2009). Theories Of Organization. Sage Publications. California.

ÜLGEN, H. ve MİRZE, S. K. (2013). İşletmelerde Stratejik Yönetim. 7. b., Beta Yayınevi, İstanbul.

VENKATRAMAN, N. ve CAMILlUS, J. C. (1984). Exploring the Concept of Fit in Strategic Management. Academy of Management Review, 9(3): 513-525.

YELOĞLU, H. O. (2008). Örgütlerde Yapısal-Stratejik Konfigürasyonlar: Koşulbağımlılık Kuramı, Konfigürasyon Yaklaşımı Bağlamında Örgüt Yapıları Üzerine Önermeler. Eskişehir Osmangazi Üniversitesi İktisadi ve İdari Bilimler Dergisi, 3(2): 155-170.

YENIÇERİ, Ö. ve İNCE, M. (2005). Bilgi Yönetim Stratejileri ve Girişimcilik. 1. Baskı. IQ Yayınları, İstanbul.

ZAJAC, E. J., KRAATZ, M. S. ve BRESSER, R. K. F. (2000). Modeling The Dynamics Of Strategic Fit: A Normative Approach To Strategic Change. Strategic Management Journal, 21(4): 429-453. 